\title{
Kill the Chickens to Scare the Monkeys
}

Ruiping Ye

2020-05-13T16:03:31

As the Chinese saying goes, killing the chickens to scare the monkeys, China's courts were quick to set examples of people who committed offences in relation to the country's response to Covid-19 in order to deter potential offenders. However, the punishments of ordinary offenders and responsible officials highlight China's constitutional setting - the dominance of the Communist Party in state affairs, and the political role of courts in times of national emergency. This is consistent with China's self-proclamation - the centrality of the Communist Party's leadership (Constitution art 1) and the division of functions among state organs without separation of powers. Under such a setting, ordinary people and officials are subject to different rules and have different fates.

\section{Punishment of Ordinary Offenders}

An important aspect in China's response to the epidemic was the swiftness to subject offenders who obstructed emergency response efforts to criminal punishment. The courts served as the enforcement arm of the government and helped the government to achieve its objectives.

In early February the Supreme Court, the Supreme Procuratorate, the Ministry of Public Security and the Ministry of Justice jointly issued a notice to their lower level counterparts, requiring "timely and severe" punishment "according to law" of offenders who obstruct the control of the epidemic. The statement meant that within the parameter of the law, punishment would be speedy and at the high end of the scale.

The official Xinhua news agency reported that, by 13 April, courts in China had dealt with 1946 cases relating to obstruction to epidemic prevention and control, of which 1196 had been concluded. To guide the application of law and sentencing, and perhaps to highlight the focus of cases and to achieve a certain degree of consistency, the Supreme Court chose and published three series of "typical cases", 26 in total, between 10 March and 15 April. Two main categories of offences are worth commenting.

The first category involved market regulation on face masks but the offences varied. A company gouged customers for facemasks and was convicted of illegal operation of business. That crime applies to three specific types of trading without licence and "other illegal operation of business seriously disrupting the market" (Criminal Law art 225). The Court found that the gouging behaviour caused or increased panic buying, disrupted social order and seriously affected the prevention and control of the epidemic. It seemed the key issue was not so much about disrupting the market as about obstructing the epidemic control. The company sold RMB170,000 (about US $\$ 24,000$ ) worth of facemasks. After pleading guilty and paying damages 
to purchasers, the company was fined RMB 200,000 , and its owner was fined RMB180,000 and sentenced to eight months imprisonment.

Two offenders who sold RMB98,000 worth of sub-standard face masks were convicted of sale of sub-standard products and were sentenced to 14 months of imprisonment and fined RMB100,000. The Court considered the sale to pharmacies as opposed to consumers an aggravating factor, although the law (Criminal Law art 140) does not allow a discretion of this nature. Two cases involved selling counterfeit trademarked facemasks. In one case the offender was convicted of selling commodities carrying counterfeit trademark, while in the other the offenders were convicted of sale of sub-standard products. This was because the Courts chose the crime with the more severe punishment in their respective circumstances, applying an earlier joint decision of the Supreme Court and the Supreme Procuraterate.

A few offenders fraudulently claimed to be selling face masks and were convicted of fraud. Article 266 of the Criminal Law prescribes supervision, criminal detention or imprisonment of no more than three years for those who gained "relatively large amount" of money, three to 10 years for "large" and over 10 years for "especially large" amount of money, plus unspecified amount of fines. Two offenders were sentenced to 10 months imprisonment and a RMB10,000 fine although no victim had made any payment. One offender was sentenced to 11 years and six months imprisonment and fined RMB150,000 for his fraudulent gain of RMB930,000.

The Supreme Court chose those cases to signal to lower courts the priority of work during Covid-19, as the punishment of such offenders was intended to deter similar activities and helped to ensure access to affordable and quality facemasks which were much needed in the pandemic.

The second category of typical cases related to the crime of obstructing infectious disease prevention and control. Article 330 of the Criminal Law criminalises actions obstructing infectious disease prevention and control causing spread or significant risk of spread of Category A diseases. The article prescribes four types of behaviour, and the relevant one in all cases was "refusing to comply with prevention and control measures established by heath and epidemic control institutions according to the Infectious Diseases Prevention and Control Law" (art 330(4)).

Except for one case which involved a clinic receiving patients with temperature without authority, the "obstruction" cases involved people concealing their travel history when asked by authorities. All were infected with Covid-19, but only in two cases were their close contacts confirmed of infection, the rest had no other consequence than causing various numbers of people to be quarantined. Those people were quickly prosecuted and convicted under art 330.

Covid-19 is classified as a category B disease even though the National Health Commission has decided to apply Category A prevention and control measures (which is allowed by the Infectious Diseases Prevention and Control Law). As art 330 only applies to Category A diseases, arguably the courts stretched the law a bit to convict those people. Article 330 offence attracts an imprisonment of up to three years or criminal detention, and three to seven years of imprisonment for 
offences that caused serious consequences. The art 330 offenders were sentenced to imprisonments of various length, between six to twelve months, despite the fact that few people were infected because of their behaviour.

One other case was interesting. As a silly joke, a man falsely claimed to have coronavirus and shared the information through Chinese chat channels. The message reached 2700 people. Within 35 days, he was sentenced to 8 months imprisonment for fabricating and spreading false information. Article 291(1) of the Criminal Law criminalises fabrication and distribution of information on an "epidemic situation" (yiqing) through information networks or on other media platforms and causing serious disruption to social order. The applicable sentences are supervision, criminal detention or imprisonment of no more than three years. There is no definition of yiqing - the term, however, suggests a broad epidemic situation rather than the personal infection of an infectious diseases. Similarly, "serious disruption to social order" is not quantified or defined. On the one hand, the law is flexible enough to catch the man's silly action. On the other hand, a close reading of the provision suggests that the conviction and punishment may be out of proportion.

Through stretching the law and heavy penalties, the courts backed the government in its epidemic responses. The publication of those cases as typical cases shows the Supreme Court's endorsement of the convictions and sentences, which would then serve as a guide for similar cases.

\section{Accountability of Officials}

The enforcement of the law vis-à-vis officials who failed their duties differed considerably. The Infectious Diseases Prevention and Control Law (ch 8) and the Emergency Response Law (ch 6) impose responsibilities on local governments and public health departments in dealing with infectious disease outbreaks and infectious diseases with unknown reasons, including timely reporting, disclosure and appropriate responses. Responsible officials who break the rules could be subject to administrative discipline or criminal penalties.

Hubei and Wuhan governments' slowness to respond to Covid-19 and to disclose relevant information to the public has drawn much criticism (for example, see Fang Fang Wuhan Diary). The World Health Organisation started to get involved as early as 1 January. The government of the Hong Kong Special Administrative Region announced the "Serious" Level (the second of three levels) of emergency alert on 4 January because of reports of cases in Wuhan, yet no official alert or warning was issued regarding Wuhan until 20 January. If anything, the public were reassured that there was no risk of infection or an outbreak. As a consequence, the general public was unprepared and many were exposed to the virus, especially as largescale official and public gatherings and travels occurred for the upcoming lunar new year. 
To be sure, Covid-19 was a new disease and there was a process of understanding it and working out suitable strategies. Western countries missed their opportunities too. But what was different about China was the action against officials.

In February, the heads of the ruling party (the Communist Party) Committees of Hubei Province and of Wuhan city were removed from their posts, following the removal of the head of the Party Committee and the director of the Hubei Public Health Commission. Interestingly, the provincial governor of Hubei and the mayor of Wuhan, who were the respective heads of the executive governments of Hubei and Wuhan, were spared.

This is revealing because it is the executive governments that are - under the Emergency Response Law 2007 and the Infectious Diseases Prevention and Control Law 1989 - in charge of carrying out the emergency response, but it was the local Party leaders that have been sanctioned. This incident is but one example to illustrate the fact that, despite legal provisions, the ruling Communist Party, not the executive government, controls the emergency response, as it does other state affairs. It was a political decision, without proper investigation of responsibilities under the law. Or in other words, the relevant provisions in law so far have not been invoked against officials who may have failed their duties in emergency response and epidemic control. In comparison to the imprisonment of individuals who obstructed the emergency response efforts, the loss of jobs by officials who failed their duties was a slight consequence. 